\title{
MITI turns up heat on research into thermophile genes
}

Tokyo. Japan's Ministry of International Trade and Industry (MITI) is stepping up its investment in genome-related research by financing the construction of a new research annexe at its Institute for Bioscience and Human Technology in Tsukuba science city, north-east of Tokyo.

The new US\$20-million annexe will analyse proteins translated from the sequenced genes of a deep-sea-vent bacterium. It will also serve as a centre for the culture collection of microorganisms that survive in extreme environments.

MITI already supports a project aimed at sequencing the entire genome of Pyrococcus shinkai, a deep-sea bacterium collected from a volcanic vent in the Okinawa trough (see Nature 374,583 ; 1985). This is one of several recent ventures by MITI into genome research, an area traditionally covered by other ministries.

MITI officials say that the agency is supporting work on thermophiles because it is interesting fundamental research and has the potential to form the basis of new industries. They argue that highly heatresistant proteins from such organisms may find future applications in devices such as biosensors and biochips.

The new annexe will employ about ten scientists and an equal number of support staff. Michio Oishi, director of the institute, who is also an adviser to the institute at which the sequencing is being carried out, says that work to be done at the annexe will benefit from his institute's existing expertise in protein crystallography.

The new annexe will also function as a centre for the collection, storage and distribution of microorganisms. Oishi says that MITI cannot afford to hire the 50 to 100 staff required to run a large-scale operation like the American Type Culture Collection. He has suggested that the new annexe focuses on what he calls "extremophiles". These are organisms which can survive in extreme temperatures and in very acid or alkali environments, as well as species collected from the inside of nuclear power generators which have adapted to highly radioactive environments.

Such a collection, which would house no more than 200 to 300 species, would complement the other work being carried out on the function of proteins from such organisms. Oishi says that his institute was chosen to house the new culture collection because it already operates a collection of several thousand prokaryotic and eukaryotic cells which have been patented. He adds that he expects the entire genome of $P$. shinkai to be sequenced by the end of next year.

Stephen Barker

\section{Head of climate group rejects claims of political influence}

London. The co-chairman of the main scientific panel of the United Nations Intergovernmental Panel on Climate Change (IPCC) this week vigorously defended the organization against suggestions that its scientists have forced through a scientific consensus on global warming to satisfy political demands.

Sir John Houghton, co-chair of IPCC working group 1 , which is responsible for reviewing the science of climate change, describes the suggestions as "a mixture of confusion and misinformation". The IPCC's second five-yearly report on climate change, which was published in London yesterday by the Cambridge University Press, is "a unique, very solid and authoritative piece of work, written by the world's best scientists", he says.

After months of detailed negotiations, the report was finalized at a conference last November in Madrid (see Nature 378, 524; 1995). But a number of what have come to be known as

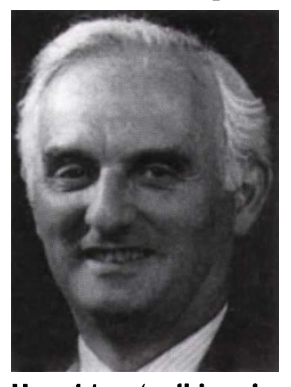

Houghton:'solid and 'contrarian' groups - authoritative' report. the energy industry, but also including scientists and economists sceptical of the IPCC maintain the panel is hostage to politicians and pressure groups convinced, despite the uncertain nature of climate predictions, that global warming exists.

In a statement issued last week, for example, John Emsley, a member of the European Science and Environment Forum (ESEF) - a group of scientists who claim to have been excluded from the IPCC process - accused the panel of censorship. Emsley, a chemist at Imperial College, London, argued that IPCC reports achieved consensus by blocking out alternative views.

Both ESEF and the Global Climate Coalition, a Washington-based fossil fuel pressure group, have repeated allegations that the IPCC 'doctored' its latest report by making last-minute changes to a portion of the approved text, without having the alterations peer-reviewed (see Nature 380, 97; 1996). But Houghton says changes were made to background documents only which IPCC rules allow - and were designed to clarify statements, and not to alter their meaning.

'Contrarian' groups also challenge the IPCC's main conclusion that the "balance of evidence" suggests that human activities are having a "discernible" influence on climate. Emsley says such a conclusion is not sup- ported by scientific papers in the report. Michael Jefferson, deputy secretary-general of the World Energy Council, an organization that has been closely involved in the IPCC process, says that although changes in climate variability and extremes are beginning to emerge, "global patterns are not yet apparent”.

But Houghton, who is to remain in his post for the third five-yearly IPCC assessment, says his critics are wrong. "There are thousands of references to support [the IPCC] conclusions," he says. "It is not an agreement about the detail, because science does not work like that. It is a general consensus about what we know and what we don't know. There is no question of forcing a consensus."

Houghton adds that he is aware of the perception that IPCC scientists are being used for political purposes. "But this is a false perception, and is not just restricted to climate change," he says, arguing that it also applies to areas such as the current debate over bovine spongiform encephalopathy.

"The job of the IPCC is to provide the policy-makers with a scientific message," says Houghton. "We do recognize that the message gets distorted when politics comes into play. That is inevitable. But it is not the scientists' fault."

Houghton says he is aware of political pressures on IPCC scientists and acknowledges that they are sometimes asked by government representatives to make prescriptive statements. "Policy-makers have said to us in the past, 'please tell us what level of $\mathrm{CO}_{2}$ we should aim for'. They would be delighted if we gave them a numerical answer. But we can't do that."

IPCC reports are written and reviewed by hundreds of authors, including government scientists as well as 'independent' scientists from academic institutions. The ability of government scientists to influence the wording of reports has led some environmentalist groups, such as Greenpeace, to call for measures to minimize political involvement.

Bill Hare, climate policy adviser for Greenpeace, says he is not against government involvement. "But I feel that at present, the balance of influence is too much in their favour."

But Houghton says any move to reduce political involvement in the IPCC would weaken the panel and deprive it of its political clout. "The presence of government scientists is vital to the IPCC," he says. "They own the findings. If governments were not involved, then the documents would be treated like any old scientific report. They would end up on the shelf or in the waste bin."

Ehsan Masood 